\title{
Rancang Bangun Sistem Informasi Penjualan Furniture pada Galeri Ukir Mebel Berbasis Web
}

\author{
Andi Wicaksono $^{(1)}$, Arie S. M. Lumenta ${ }^{(2)}$ Brave A. Sugiarso $^{(3)}$ \\ Teknik Informatika, Universitas Sam Ratulangi, Manado, Indonesia. \\ Email: andiwisn@gmail.com, al@unsrat.ac.id, brave@unsrat.ac.id
}

\begin{abstract}
Abstrak ---Dalam membangun suatu sistem informasi yang baik diperlukan adanya rancangan yang dapat memberikan kemudahan bagi para penggunanya.Tidak hanya memberikan kemudahan bagi para penggunanya tetapi juga sistem informasi tersebut dapat memberikan informasi yang cepat dan akurat. Galeri Ukir Mebel merupakan sebuah usaha menengah yang bergerak di bidang kerajinan mebel seperti kursi tamu, meja makan, lemari, dan lain-lain. Informasi yang di berikan Galeri Ukir Mebel hanya bisa mempromosikan sekitar wilayah tertentu degan cara penawaran manual dalam hal penjualan, dimana pelanggan masih menggunakan sistem konvensional dan hanya memesan barang yang sudah ada, belum adanya sistem informasi yang mempromosikan Galeri Ukir Mebel secara online.Peneliti mengususlkan sebuah sistem yang dapat memasarkan kerajinan mebel dari Galeri Ukir Mebel melalui internet dan dapat menyimpan dan memproses data pemesanan pelanggan agar lebih efisisen. Websitedikembangkan menggunakan bahasa pemrograman PHP dengan Mysql sebagai basis datanya. Metode pengembangan sistem yang digunakan adalah Rapid Application Development (RAD), Data Flow Diagram (DFD) sebagai penggambaran sistem dan Adobe Dreamwever CS6 sebagai editor profesional untuk mendesain Web secara visual. Pada Sistem Informasi Penjualan Furniture pada Galeri Ukir Mebel berbasis Web ini, pemilik bisa mempromosikan hasil produksinya kepada konsumen dengan lebih efisien, serta memberikan informasi yang akurat seputar produk. Konsumen juga memperoleh kemudahan dalam mengakses ketersediaan barang produksi sehingga berpotensi untuk meningkatkan angka penjualan hasil produksi. Sistem penjualan ini dapat membantu Galeri Ukir Mebel sebagai media penjualan dan mempromosikan hasil produksinya kepada konsumen dengan lebih mudah, serta memberikan informasi mengenai update barang hasil produksi dengan lebih cepat.
\end{abstract}

Kata kunci : Sistem, E-Commerce, Furniture, Entity Relationship Diagram, Rapid Application Development,

\section{I.PENDAHULUAN}

Teknologi saat ini sudah semakin berkembang, sehingga semakin memberikan kemudahan bagi kita untuk saling berkomunikasi satu dengan yang lainnya. Kemudahan berkomunikasi ini ditentukan oleh desain dari bentuk jaringan tersebut apakah sesuai dengan keadaan dari lokasi yang akan kita gunakan atau tidak, demikian juga dalam merancang sebuah sistem informasi. Sebuah sistem informasi yang baik adalah sebuah sistem informasi yang dapat menyediakan informasi yang diperlukan oleh penggunanya.

Dalam dunia komunikasi sekarang ini dituntut suatu layanan informasi yang dapat diakses dari manapun. Internet merupakan salah satu layanan informasi yang memberikan kemudahan untuk mengakses sebuah web yang dapat memberikan berbagai macam informasi. Web merupakan ruang informasi di internet tempat dokumen-dokumen disimpan yang dapat diambil dari alamat tertentu. Dengan demikian web merupakan suatu media penyampaian informasi yang dengan mudah dapat diakses dari jaringan internet.

Sistem informasi berbasis web kini menjadi suatu hal yang penting bagi pemenuhan kebutuhan informasi. Banyak bidang yang telah memanfaatkan sistem informasi berbasis web sebagai sarana untuk mempermudah mendapatkan informasi yang digunakan mulai dari kalangan pembisnis, usahawan sampai kalangan akademis atau pendidikan. Kemudahan mendapatkan informasi secara mudah, cepat, dan akurat telah menjadi suatu kebutuhan manusia modern saat ini.

Galeri Ukir Mebel merupakan sebuah usaha menengah yang bergerak di bidang kerajinan mebel seperti kursi tamu, meja makan, lemari, dan lain-lain. Informasi yang di berikan Galeri Ukir Mebel hanya bisa mempromosikan sekitar wilayah tertentu antara lain Manado, Tomohon, Bitung, Kotamubagu, dan Gorontalo degan cara penawaran manual dalam hal penjualan, dengan demikian informsi hasil kerajinan juga harus menjangkau kepada pelanggan berdasarkan wilayah yang di jangkau oleh Galeri Ukir Mebel.

Kesulitan pelanggan untuk memperoleh informasi mengenai data produk merupakan salah satu kendala yang dihadapi karena untuk melihat informasi mengenai produk yang dibutuhkan, pelanggan harus datang ke toko untuk mengetahui informasi secara terperinci. Hal ini menyebabkan banyak waktu terbuang yang dibutuhkan pelanggan untuk memperoleh informasi. Selain itu untuk melakukan pembelian, pelanggan juga dipersulit dengan tidak adanya sistem yang mempermudah pelanggan untuk melakukan pembelian selain dengan datang langsung ke toko. Kendala seperti ini akan berdampak pada berkurangnya niat pelanggan untuk melakukan transaksi pada pelanggan yang tidak mendapatkan informasi mebel di zaman serba praktis ini.

\section{LANDASAN TEORI}

\section{A. Konsep Dasar Sistem Informasi}

Sistem informasi dapat didefinisikan menjadi 2 bagaian yaitu Sistem dan Informasi. Sistem didefinisikan dengan pendekatan prosedur dan dengan pendekatan komponen. Dengan pendekatan prosedur, sistem dapat didefinisikan sebagai kumpulan dari prosedur-prosedur yang mempunyai tujuan tertentu. Dengan pendekatan komponen, sistem dapat didefinisikan sebagai kumpulan dan komponen yang saling berhubungan satu dengan yang lainnya membentuk satu kesatuan untuk mencapai tujuan tertentu.

Sedangkan pengertian informasi, informasi merupakan data yang telah di olah dan diaturulang menjadi suatu bentuk yang lebih berarti dan di tunjukan untuk seseorang. Informasi di bentuk dari kombinasi data, yang di harapkan memiliki arti bagi yang menerimanya.

Sistem informasi adalah sebuah sistem yang mengumpulkan, mengolah, menyimpan dan menganalisa data, serta memimsahkan informasi untuk tujuan yang spesifik [3].

\section{B. Internet}

Internet kependekan dari interconnection-networking adalah seluruh jaringan komputer yang saling terhubung menggunakan standar sistem global Transmission Control Protocol/Internet Protocol Suite (TCP/IP) sebagai protokol pertukaran paket (packet switching communication protocol). Internet dapat diartikan 
sebagai jaringan komputer luas dan besar yang mendunia, yaitu menghubungkan komputer dari suatu negara ke negara lain di seluruh dunia, dimana di dalamnya terdapat berbagai sumber daya informasi dari mulai yang statis hingga yang dinamis dan interaktif.

Internet adalah sebuah jaringan world wide, bentuk jaringan bebas menggunakan jaringan line telepon, dari jutaan pengguna diseluruh dunia yang membuat koneksi melalui modem dapat berkomunikasi satu sama lain [3]

\section{Konsep Dasar Web}

Secara terminology, website adalah kumpulan dari halamanhalaman situs yang biasa terrangkum dari sebuah domain atau subdomain, yang tempatnya berada di World Wide Web di internet. Website merupakan kumpulan halaman yang menampilkan informasi data, teks, gambar, data animasi, suara dan gabungan dari semuanya, baik yang bersifat dinamis maupun yang bersifat statis yang membentuk suatu rangkaian bangunan yang saling terkait dengan jaringan-jaringan halaman atau Hyperlink.

\section{E_Commerce}

E-Commercemerupakansebuah perubahan bentuk dari kompetisi,kecepatan dari sebuah aksi, dan garis interaksi produk, dan pembayarandari pelanggan kepada perusahaandan dari perusahaan kepada pemasok.

E-Commerceadalah kegiatan membeli dan menjual barang ataujasa yang berlangsungsecara digital dalam lingkungan jaringan internet.

E-Commercemenyediakan pintu gerbang bagi pegawai, manajer,pelanggan (klien) yang ingin memulai usaha dan dipercaya sepenuhnyaoleh pemasok dan rekan penjual untuk jalur aplikasi data elektronik dansemua informasi yang mereka butuhkan.

E-Commercedapat didefinisikan sebagai segala bentuk transaksiperdaganganatauperniagaan barang atau jasa (trade of goods and service)dengan menggunakan media elektronik.

E-Commercedigunakan sebagai transaksi bisnis antara perusahaanyang satu dengan perusahaan lain, antara perusahaan dengan pelanggan,atau antara perusahaan dengan institusi yang bergerak dalam bidangpelayanan publik. Jika di klarifikasikanECommerceterbagi menjadi tigatipe aplikasi, yaitu :

1. Elektronik Markets(EMs)

EMsadalah sebuah sarana yang menggunakan teknonlogiinformasi dan komunikasi untuk melakukan penawaran dalam sebuahsegmen pasar, sehingga pembeli dapat membandingkan berbagaimacam harga yang ditawarkan. Keuntungan fasilitas EMS bagupelanggan adalah terlihat lebih nyata dan efisien dalam hal waktu.Sedangkan bagi penjual, dapat mendistribusikan informasi mengenaiproduk danserviceyang di tawarkan dengan lebih cepat sehinggadapat menarik pelanggan lebih banyak.

2. Electonic Data Incharge(EDI)

EDI adalah saran untukmengefisienkan pertukaran datatransaksi-transaksi regular yang berulang dalam jumlah besar antaraorganisasi-organisasi komersial. Secara formal EDI didefinisikan olehInternational Data ExchangeAssociation(IDEA) sebagai "transferdata terstruktur dengan format standartyang telah disetujui yangdilakukan dari satu sistem komputer ke sistem komputer yang lainmenggunakan media elektronik". Keuntunganmenggunakan EDIadalah waktu pemesanan yang singkat, mengurangi biaya, mengurangikesalahan, memperoleh respon cepat, pengiriman faktur yang cepatdan akurat serta pembayaran dapat dilakukan secara elektronik.

3. Internet Commerce

Internet Commerceadalah pengunaan internet yang berbasisteknologi informasi dan komuniskasi perdagangan. Kegiaatankomersial ini seperti iklan dalam penjualan produk dan jasa.Keuntungan dariinternet commerceantara lain harga lebih murahmengingat membuat situs diinternet lebih murah biayanyadibandingkan membuka outlet retail di berbagai tempat, pembelianmelalui internet akan diikuti dengan layanan pengantaran barangsampai di tempat pemesanan.

Karakteristik E-Commerce

TransaksiE-Commercememiliki beberapa karakteristik yangsangat khusus, yaitu :

1. Transaksi Tanpa Batas

Dengan adanya internet, perusahaan dapat memasarkanproduknya secara internasional cukup dengan membuat situswebataudengan memasang iklan diinternettanpa batas waktu.

2. Transaksi Anonim

Parapenjual dan pembeli dalam transaksi melalui internet tidakharus bertemu muka satu sama lainnya. Penjual tidak memerlukannama dari pembeli sepanjang mengenai pembayarannya telahdiotorisasi oleh penyedia sistem pembayaran yang ditentukan, yangbiasanya dengan kartu kredit.

3. Produk digital dan non digital

Dalam perkembangannya produk yang dijual melalui $E$ Commercedapat berupa produk digital maupun non digital.

Kategori E-Commerce

Menurut referensi [8],ada 4 kategori dariE-Commerceyaitu:

1. Businessto Business (B2B)

Business to business, aktivitas mengarah kepandangan penuhpadaE-Commerceyang dimana dapat terjadi antara dua (2) organisasi,diantara aktivitas lainnya, ini termasuk pembelian, penyediaan barang,supplier management, inventory management, sales activities, danservice and support.

2. Business To Consumer (B2C)

BusinessTo ConsumeradalahE-Commerceyang mengarahkepada pertukaran antara bisnis dan konsumen, seperti yang dilakukanoleh Amazon,Yahoo, Dan Charles Schwab \& Co. Transaksi B2Cdapat berupa pertukaran fisik atau produkdigitalatau pelayanan danbiasanya lebih kecil daripada transaksi yang dilakukan model B2B.

3. $\quad$ Peer to Peer (P2P)

PeertoPeer (P2P)adalah pertukaran yang terjadi antarakonsumen dengankonsumen. Pertukaranbisamelibatkan pihakketiga.

4. Consumer to business (C2B)

Konsumen dapat bersatu bersama untuk menampilkan merekasebagai grup pembeli dalam hubunganC2B.Termasuk dalam kategoriini adalah perorangan yang menjual produk atau layanan ke organisasi,dan perorangan yang mencari penjual, berinteraksi dengan mereka danmensepakati suatu transaksi.

\section{E.Model RAD (Rapid Application Development)}

Model RAD (pada gambar 1)adalah sebuah model proses perkembangan perangkat lunak yang menekankan pada siklus perkembangan cepat dengan menggunakan pendekatan kostruksi berbasis komponen. Sebingga apabila kebutuhan di pahami dengan baik, maka sistem fungsional yang utuh dapat di selesaikan dengan waktu kira-kira 60-90 hari. Menurut referensi [5] fase dalam RAD dibagi menjadi empat, yaitu :

1. Fase Perencanaan Syarat-syarat

Pada fase ini pengguna memutuskan fungsi apa saja yang harus difiturkan oleh aplikasi tersebut.

2. Fase Desain Pengguna

Pada fase ini pengguna diminta membahas aspek-aspek desain non-teknis dari sitem dengan bimbingan penganalisis. Karena tingginya sifat interaktif, fase ini sering digabungkan dengan fase konstruksi pada workshop desain RAD.

3. Fase Konstruksi

Pada fase ini setiap desain yang diciptakan dalam fase sebelumnya selanjutnya ditingkatkan untuk dilakukan 
pengkodean sistem. Kemudian setelah tahap ini selesai dilakukan uji kemampuan untuk mendapatkan komentar, dan revisi dari pengguna.

4. Fase Pelaksanaan

Tahap terakhir adalah dimana aplikasi baru diuji coba dan pengenalan terhadap aplikasi.

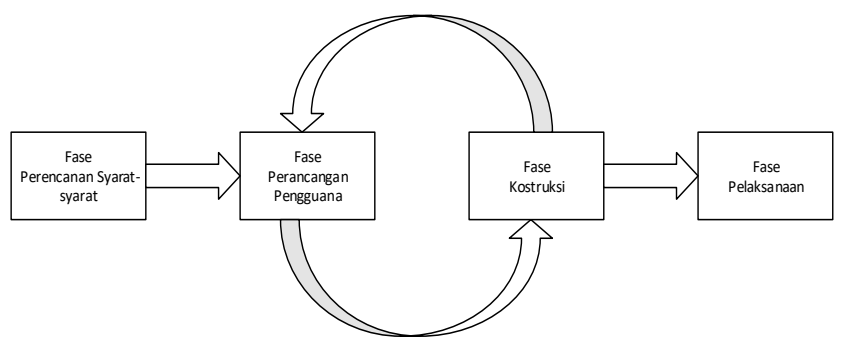

Gambar 1. Fase RAD (Kendal \& Kendal, 2003:238)

\section{F. Bagan Alir (FlowChart)}

Bagan alir atau flowchart merupakan alat bantu berbentuk grafik yang dapat digunakan untuk menunjukan urutan kegiatan dari sistem informasi berbasis komputer. Bagan alir ini memperlihatkan urutan proses dalam system dengan mennunjukan alat media input, output, serta jenis media penympanan dalam proses pengolahan data [1].

\section{G. Data Flow Diagram (DFD)}

Data Flow Diagram (DFD) adalah alat pembuatan model yang memungkinkan professional sistem untuk menggambarkan sistem sebagai suatu jaringan proses fungsional yang dihubungkan satu sama lain dengan alur data, baik secara manual maupun komputerisasi. DFD ini sering disebut juga dengan nama Bubble chart, Bubble diagram, model proses, diagram alur kerja, atau model fungsi.

DFD ini adalah salah satu alat pembuatan model yang sering digunakan, khususnya bila fungsi-fungsi sistem merupakan bagian yang lebih penting dan kompleks dari pada data yang dimanipulasi oleh sistem. Dengan kata lain, DFD adalah alat pembuatan model yang memberikan penekanan hanya pada fungsi sistem.

DFD ini merupakan alat perancangan sistem yang berorientasi pada alur data dengan konsep dekomposisi dapat digunakan untuk penggambaran analisa maupun rancangan sistem yang mudah dikomunikasikan oleh profesional sistem kepada pemakai maupun pembuat program [1].

\section{H. Entity Relationship Diagram (ERD)}

Entity Relationship Diagram merupakan suatu model untuk menjalankan hubungan antar data dalam basis data berdasarkan objek-objek dasar data yang mempunyai hubungan antar relasi. ERD untuk memodelkan struktur data dan hubungan antar data, untuk menggambarkannya digunkan beberapa notasi dan simbol.

a. Entity : Entity merupakan objek yang mewakili sesuatu yang nyata dan dapat dibedakan dari suatu yang lain. Simbol dari entity ini biasanya di simbolkan dengan persegi panjang.

b. Atribut : Setiap entitas pasti mempunyai elemen yang disebut atribut yang berfungsi untuk mendeskripsikan karakteristik dari entitas tersebut. Isi dari atribut mempunyai sesuatu yang dapat mengidentifikasikan isi elemen satu dengan yang lain. Gambar atribut diwakili dengan simbol elips.

c. Hubungan / relasi : Hubungan antara sejumlah entitas yang berasal dari himpunan entitas yang berbeda.

\section{Page Hypertext Preprocessor (PHP)}

PHP atau Page Hypertext Preprocessor adalah bahasa yang bersifat server side yang memiliki kemampuan untuk dikombinasikan dengan teks, HTML, dan komponen-komponen lain untuk membuat suatu halaman web lebih menarik, dinamis, dan interaktif. Dengan beberapa kemudahan yang dimiliki oleh PHP, diharapkan pengembang halaman web menjadi mudah dan lebih cepat berkerja. Pada awalnya, PHP diciptakan oleh Andi
Gutmans untuk menghitung berapa banyak pengunjung yang mengakses homepage yang dibuat olehnya.

Seiring dengan perkembangan internet, dirilis PHP dan selanjutnya PHP2. Dari sekelompok orang salah satunya Rasmus Lerdort dirilis PHP3 yang merupakan penyempurnaan dari versi sebelumnya. Dalam versi ini, PHP3 telah mampu digunakan untuk membangun aplikasi web dengan koneksi database yang cukup banyak. Namun hanya bekerja dengan baik pada website yang tidak begitu kompleks. Versi PHP4 merupakan pengembangan dari versi PHP3 dengan menambahkan fungsi-fungsi seperti zend engine sehingga lebih cepat, kuat, stabil, mudah untuk berinteraksi dengan berbagai aplikasi pendukungnya.

\section{J. Hyper Text Markup Language (HTML)}

HTML (Hyper Text Markup Language) dikembangkan pertama kali pada tahun 1989 oleh Tim Barners-Lee. Bahasa skrip in memungkinkan penyajian informasi dalam bentuk teks dengan tautan yang bisa mengaitkan berbagai server. Aplikasi-aplikasi web yang kita nikmati sekarang adalah berkat HTML tersebut.

HTML 4.0 diperkenalkan oleh World Wide Web Consortium (W3C) pada Desember 1997, yang antara lain menyertakan fitur CSS (Cascading Style Sheets), yang mendukung pembuatan aplikasi yang dinamis. Tahun 1999 muncul HTML 4.1 Setelah kemunculan HTML 4.1, XHTML 1 lahir. Secara prinsip spesifikasi pada XHTML sama seperti sama seperti pada XHTML 4.01. hal yang membedakan adalah sintaks bahasanya. XHTML menerapkan aturan yang lebih ketat dari pada HTML, yakni mengharuskan pembuat dokumen harus mengikuti aturan XML (eXtended Markup Language). Selain itu, dalam penulisan dokumen semua tag dan atribut dalam dokumen harus ditulis dengan menggunakan huruf kecil, sementara pada HTML, tag dan atribut boleh di tulis dengan huruf capital, huruf kecil, ataupun kombinasinya. XHTML 1.0 diteruskan dengan XHTML 2.0. Namun, versi yang terbaru ini kurang mendapat tanggapan dari para vendor.

Bagaimana halnya dengan HTML 5? HTML5 (angka 5 dan HTML tidak dipisahkan oleh spasi) dikembangkan oleh badan lain yaitu WHATMG (Web Hypertext Application Technology Working Grup). Spesifikasi HTML5 belum final saat buku ini ditulis, tetapi diyakini oleh banyak orang akan menjadi standar yang diterima di masa depan. Walaupun belum final, HTML5 telah menebar pesona.

Pada HTML5, kekangan dalam menuliskan tag dan atribut dengan huruf kecil tidak ada lagi. Anda mempunyi kebebasan untuk menggunakan huruf kecil, huruf capital, atau kombinasinya Bahkan, nilai suatu atribut mau diberi tanda petik atau tidak sama saja. Browser tidak lagi memperdulikan hal-hal seperti itu.

HTML5 menawarkan berbagai fitur menarik yang tidak didukung oleh HTML sebelumya. Beberapa fitur yang tersedia pada HTML antara lain sebagai berikut.

5. Canvas. Memungkinkan pembuatan gambar dalam kanvas. Jadi, gambar tidak lagi di ambil dari gambar utuh , melainkan bisa di susun sendiri, bak mengiakan program paint.

6. Header. Berguna untuk menyatakan suatu judul, yang bisa di isi dengan logo dan nama perushaan.

7. Footer. Merupakan kebalikan dari Header. Sebagai catatan kaki, elemen ini berguna untuk menaruh informasi di bagian bawah halaman Web.

8. Time. Elemen ini berguna untuk menyajikan informasi tentang waktu.

9. Audio. Memungkinkan penyajian player untuk memutar suara.

10. Video. Memungkinkan player untuk memainkan film.

\section{Adobe Dreamweaver CS6}

Adobe Dreamweaver CS6 adalah versi terbaru dari Adobe Dreamweaver yang merupakan bagian dari Adobe Creative Suit 6 . Adobe Dreamweaver sendiri merupakan aplikasi yang digunakan sebagai HTML editor profesional untuk mendesain Web secara visual. Aplikasi ini juga bisa dikenal dengan istilah WYSIWYG (What You See Is What You Get), yang intinya adalah kita tidak 
harus berurusan dengan tag-tag HTML untuk membuat sebuah site dan dapat melihat hasil desainnya secara langsung.

\section{METODE PENELITIAN}

A. Bentuk - bentuk metode penelitian penulis sebagai berikut:

1. Objek Penelitian

Pelaksnaan penelitian dilakukan di industri Mebel Wonasa Kapleng dengan waktu 1 bulan. Proses ini di lakukan pada bulan September 2016 sampai Oktober 2016.

2. Metode Pengumpulan Data

Metode penelitian yang diterapkan dalam mendapatkan data dan informasi yang mendukung dalam penelitian ini, sebagai berikut:

a. Studi Pustaka

Penelitian kepustakaan digunakan sebagai dasar pembahasan secara teoritas, teori-teori dan pandangan dari buku-buku, bahan kuliah, pencarian melaui internet dan sumber-sumber lainnya dalam penulisan karya tulis ini.

b. Studi Lapangan

Dalam melakukan penelitian di lapangan akan didapatkan data yang terdapat dalam dokumen-dokumen instantsi terkait, serta langsung mengamati, mengevaluasi system informasi penjualan pada perusahaan lain juga akan dilakukan wawancara dengan narasumber atau pihak-pihak yang berhubungan degan masalah tersebut:

a. Wawancara, yaitu dengan langsung bertatap muka dengan pihak-pihak terkait yaitu pemilik suatu usaha dan konsumen di suatu perusahaan tersebut.

b. Observasi, yakni dengan melakukan pengamatan lasngsung terhadap hal-hal yang berhubungan dengan system pemesanan tersebut. Observasi dilakukan pada Galeri Ukir Mebel.

3. Analisa Kebutuhan Masalah

1. Analisa Sistem Yang Sedang Berjalan

Sistem yang berjalan pada galeri ukir mebel adalah sebagai berikut:

a. Informasi dari produk disebarkan melalui promosi dari mulut ke mulut, dan media masa lainya kepada masyarakat umum.

b. Pemesanan dan pembelian oleh konsumen dilakukan dengan cara datang langsung ke toko.

2. Kelemahan Sistem Yang Berjalan

Berdasarkan analisa sistem yang berjalan pada, maka di dapat kelemahan sistem yang berjalan sebagai berikut :

a. Promosi produk yang dilakukan menggunakan media konvensional seperti promosi dari mulut ke mulut dan media cetak kurang efektif karena tidak menjangkau pembeli secara luas.

b. Pembeli harus datang sendiri untuk membeli produk yang di ingikannya sehingga pembeli hanya terbatas pada orang yang mau datang ke tempat penjulan saja.

c. Data pembelian yang dicatat secara manual juga berpotensi terjadi kesalahan.

3. Solusi Pemecahan Masalah

Pemecahan masalah yang penulis lakukan dalam menyelesakan masalah adalah dengan pembuatan aplikasi pemesanan secara online berbasis web. Website yang di buat dijadikan sebagai media promosi skaligus untuk memesan barang dimana penjual telah memasukan data barang yang akan di jual.

4. Analisa Sistem Yang Diusulkan

Dengan adanya website pemesanan barang, masyarakat yang ingin mencari informasi produk mengenai mebel tidak perlu repot untuk datang langsung ke mebel dan masyarakat bisa mengakses website tersebut melalui komputer tanpa ada batasan waktu. Konsumen juga dapat melakukan pemesanan langsung secara online.

4. Fase Perancagan

Tahap selajutanya dalama RAD setelah menganalisi masalah pada sistem yang berjalan adalah tahap perancangan sistem yang bertujuan untuk mengatasi permasalahan yang ada dan memberikan usulan rancangan sistem.

\section{B. Perancangan Data Flow Diagram (DFD)}

DFD merupakan alat perancangan sistem yang berorientasi pada alur data dengan konsep dekomposisi yang dapat digunakan untuk penggambaran analisa maupun rancangan sistem yang mudah dikomunikasikan oleh profesional sistem kepada pemakai maupun pembuat program. Berikut meruapakan gambaran umum website pemesanan online dalam bentuk DFD.

Diagram konteks pada gambar 2 merukapan diagram yang memperlihatkan aplikasi sebagai bentuk satu proses yang terjadi atau pemetaan yang terjadi.

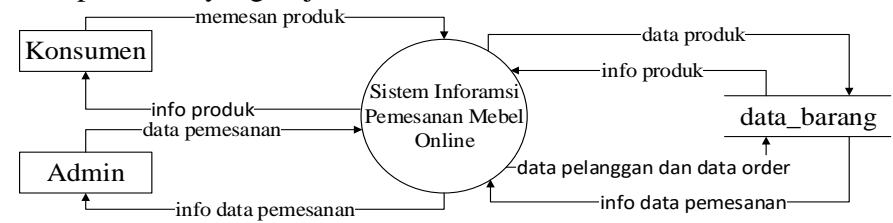

Gambar 2 Diagram Konteks

\section{Entity Relationship Diagram (ERD)}

Perancangan basis data ini termasuk di dalamnya meliputi bentuk ERD yang berikutnya akan di implementasikan dalam bentuk tabeltabel dengan keterkaitan atau keterhubungannya diantara tabel tersebut. Perancangan DFD yang telah digambarkan sebelumnya kemudian dilanjutkan dengan peracangan database yang akan digunakan pada aplikasi ini dengan penggambaran database yang akan digunakan pada aplikasi ini dengan penggambaran database ERD pada gambar 3 :

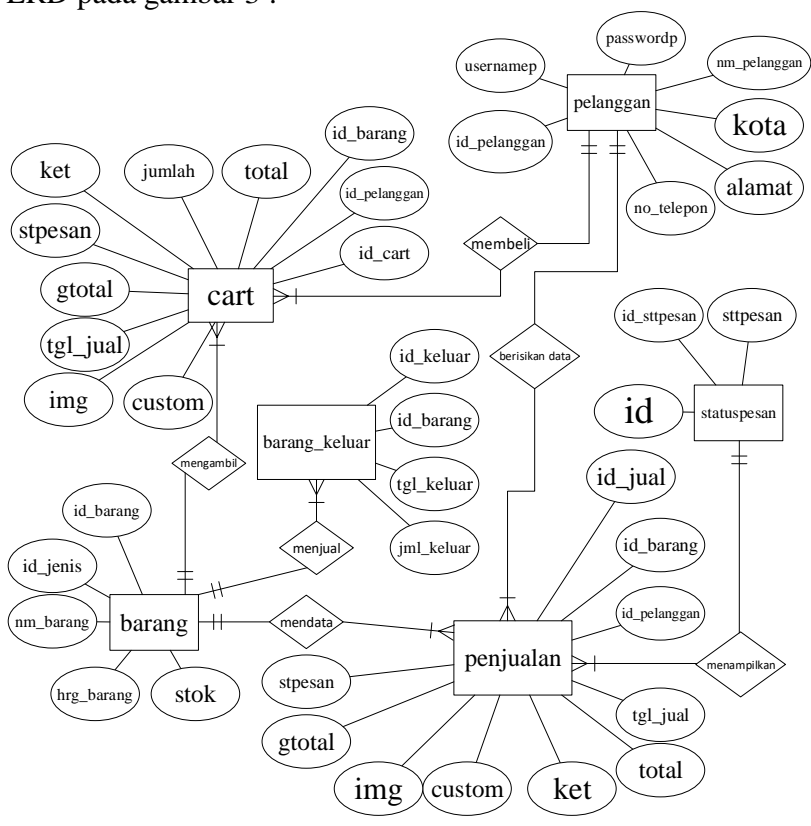

Gambar 3Entity Relationship Diagram (ERD) 


\section{Rancangan Antar Muka Program}

Untuk mempermudah dalam perancangan sistem maka penulis memvisualisasikan antarmuka halaman Web yang dibangun sehingga dapat memberikan gambaran dari aplikasi yang di hasilkan.

1. Halaman Utama

\begin{tabular}{|c|}
\hline header \\
konten/isi \\
\hline penjualan \\
footer \\
\hline
\end{tabular}

Gambar 4 Rancangan Tampilan Awal Halaman Katalog

Pada gambar 4 header terletak pada bagian bagian atas halaman, pada header terletak 2 button yaitu login dan penjualan. Button login digunakan untuk admin dan pada penjualan digunakan untuk user. Konten/Isi berisi list informasi barang yang di tawarkan pada bagian tengah halaman.

\section{Halaman Menu Admin}

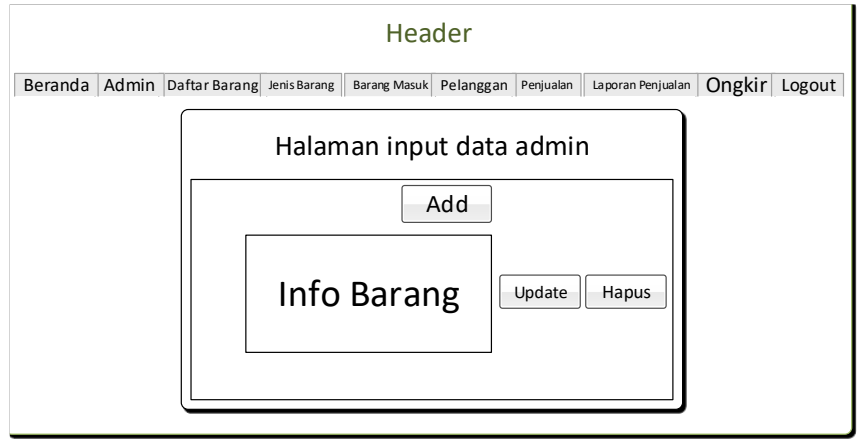

Gambar 5 Rancangan Halaman Menu Admin

Header terletak pada bagian atas halaman di mana pada atas halaman tertulis menu admin, dan terdapat button untuk admin. Dan pada tengah halaman terdapat info edit admin. Dan terdapat button update dan delete.

\section{HASIL DAN PEMBAHASAN}

\section{A. Implementasi Sistem}

Dalam pengoperasian sistem ini diatur dalam 3 jenis pengguna (user) yang masing-masing memiliki otoritas dan tingkatan tertentu dalam mengakses sistem yang berjalan, yaitu :

1. Pembeli

2. Admin

3. Tamu

B. Tampilan Sistem Informasi Penjualan Mebel

1. Halaman Home

Halaman awal dari gambar 6 tampilan penjualan yang berisi tentang informasi yang di tawarkan mengenai barang katalog. Halaman ini merupakan halaman pertama disaat kita mengujungi web Penjualan Mebel Online. Ini merupakan halaman index yang didalamnya terdiri dari informasi umum.
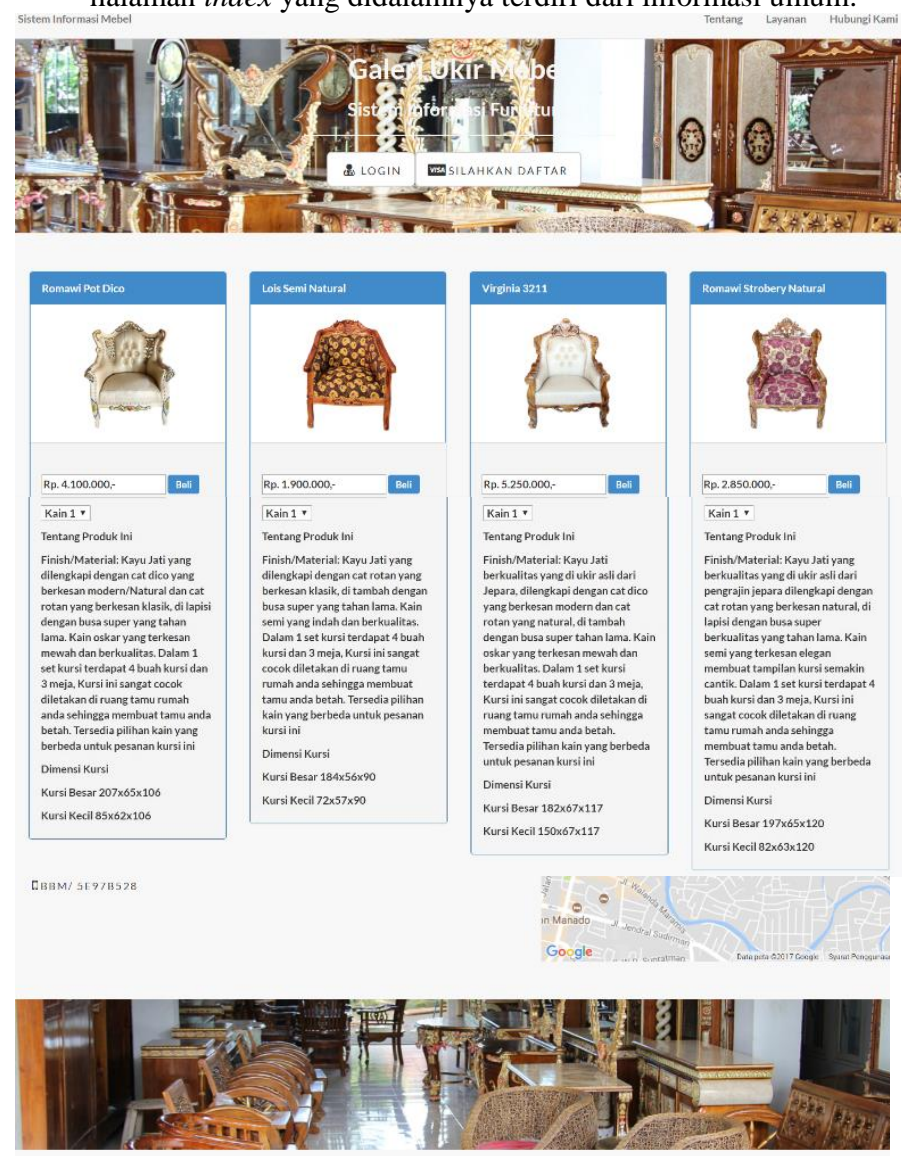

\section{Beranda . Tentang : Lypranan . Hubungik Kan}

Gambar 6 Halaman Utama Sistem Informasi Penjualan Mebel

2. Halaman Pendaftaran Pelanggan Baru

Halaman daftar pelanggan baru pada gambar 7 digunakan oleh calon pembeli untuk mengisi identitas sesuai yang disediakan seblum dapat melukukan pembelina barang.

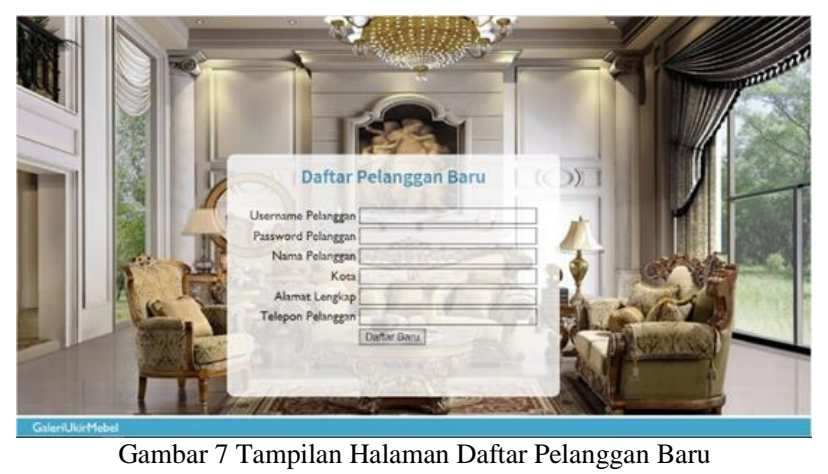

\section{Halaman Login}

Halaman pada gambar 8 adalah Login untuk User yang ingin melakukan pembelian mereka harus terdaftar dulu sebagai pelanggan sebelum melakukan order barang. 


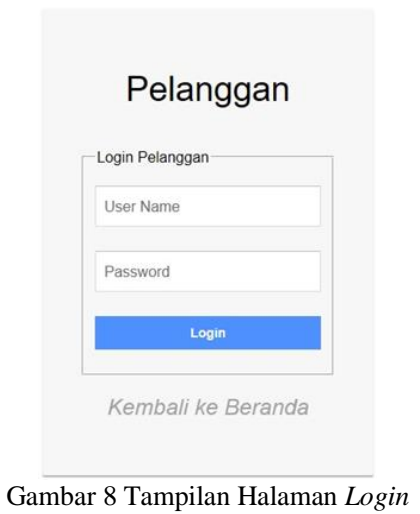

4. Halaman Pemesanan

Ketika pelanggan ingin membeli dan menekan BELI pada barang yang diinginkan maka akan muncul popup seperti pada gambar 9 Dimana pelanggan bisa meihat harga dan jumlah barang dengan menggeser jumlah beli dan menambahkanya ke keranjang.

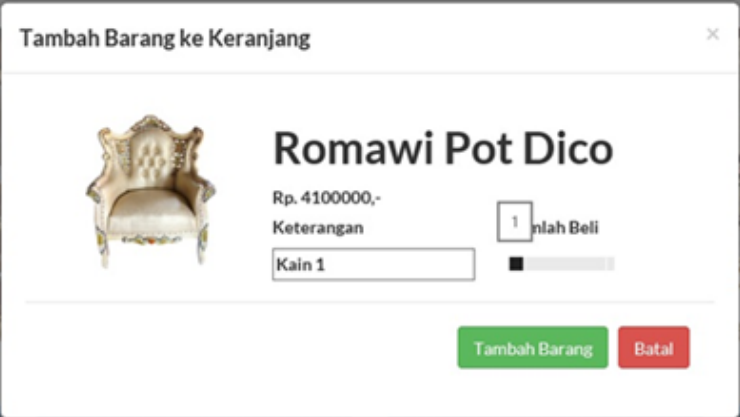

Gambar 9 Halaman Pemesanan Barang

\section{Halaman Informasi Pembelian}

Halaman pada gambar 10 digunakan oleh pembeli untuk mendapatkan informasi pembayaran. Pembayaran sendiri masih manual dengan cara transfer. Disini pelanggan mendapatkan info tentang jumlah yang harus di bayar dan no rekening yang akan di transfer. Pelanggan juga dapat membatalkan pesanan,kembali memesan, atau langsng membayar (checkout).

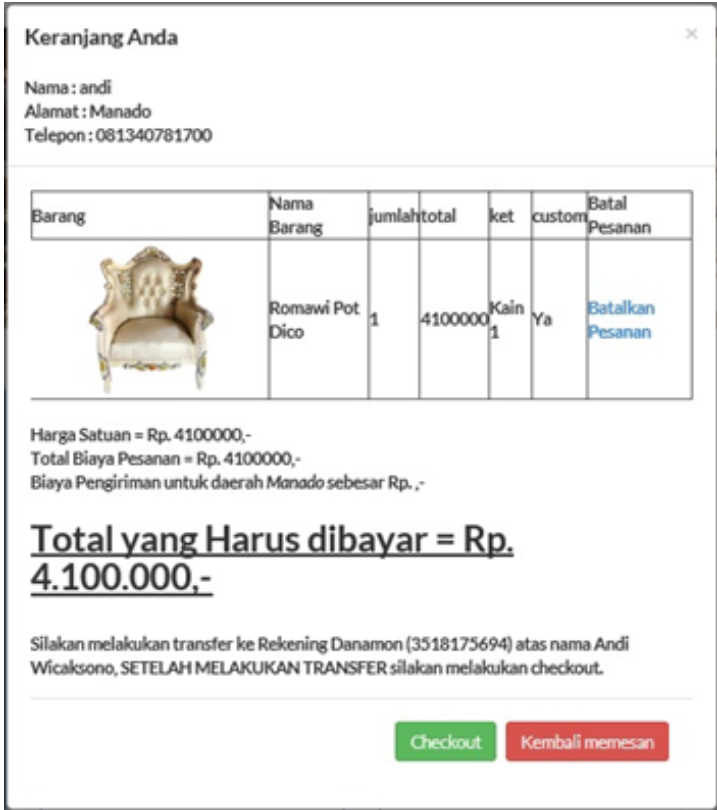

Gambar 10 Halaman Informasi Pemesanan
6. Halaman Status Pesan

Halaman pada gambar 11 menunjukan info tentang status pembelian yang di lakukan oleh pelanggan, dimana pelanggan dapat mengetahui barang yang di pesan akan di proses, dari penginfoan pembayaran dan pengiriman. Pelanggan juga dapat kembali memesan bila ada barang yang ingin di tambahkan.

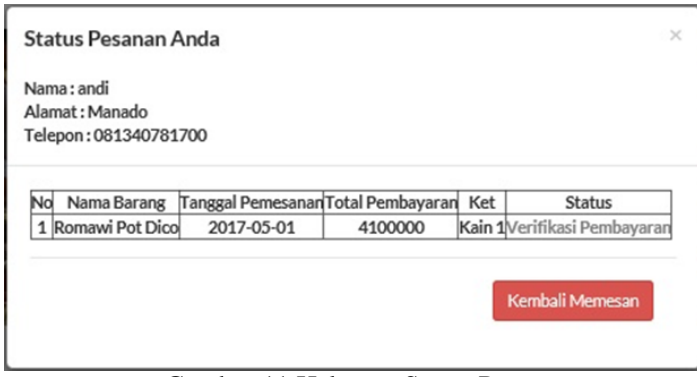

Gambar 11 Halaman Status Pesan

7. Halaman Admin Daftar Data Penjualan

Halaman pada Gambar 12 memberikan info arsip dan data penjualan, dalam adata penjualan ini admin dapat mengubah status pemesanan barang.

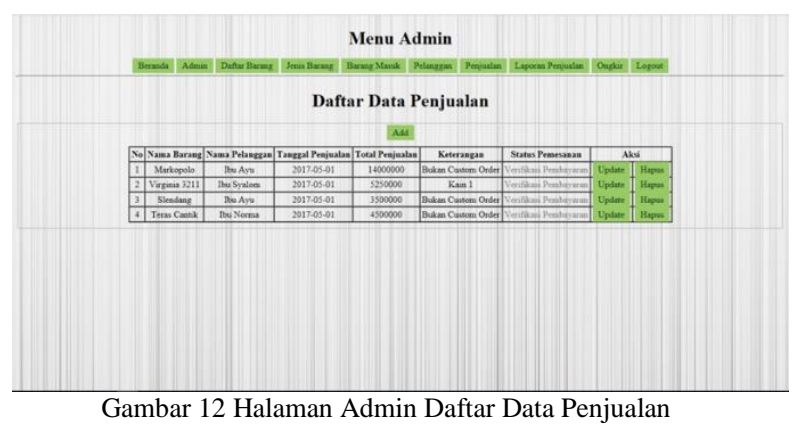

V. PENUTUP

A. Kesimpulan :

1. Dengan dibuatnya Sistem Informasi Penjualan Furniture pada Galeri Ukir Mebel berbasis Web ini, pemilik bisa mempromosikan hasil produksinya kepada konsumen dengan lebih mudah, serta memberikan informasi mengenai update barang hasil produksi dengan lebih cepat dan lebih mudah. Konsumen juga memperoleh kemudahan dalam mengakses ketersediaan barang produksi sehingga berpotensi untuk meningkatkan angka penjualan hasil produksi.

2. Dengan dibuatnya Sistem Informasi Penjualan Furniture pada Galeri Ukir Mebel berbasis Web ini, wilayah pemasaran dapat diperluas sehingga dapat mencakup wilayah diluar Sulawesi. Hal ini dapat meningkatkan jumlah konsumen dan dapat meningkatkan jumlah keuntungan.

B. Saran :

1. Untuk mengoptimalkan penggunaan sistem informasi web ini, maka admin yang mempunyai akses penuh dalam sistem tersebut dapat di berikan pelatihan terlebih dahulu. Agar nantinya tidak menemukan kesulitan dalam penginputan data.

2. Untuk menambahkan kebutuhan dalam memberikan pelayanan informasi di mebel, maka sistem informasi ini dapat dikembangkan sewaktu-waktu sesuai dari kebutuhan informasi yang diperlukan. Karena untuk 
sementara ini masih di batasi pada beberapa pelayanan informasi saja.

\section{DAFTAR PUSTAKA}

[1] B. Ladjamudin, Al-Bahra. Analisis dan Desain Sistem Informasi. Graha Ilmu, Yogyakarta. 2005.

[2] E. Handoyono. Aplikasi Pemesanan Part Motor Berbasis Web. Jakarta : Skripsi Program Studi Teknik Informatika Fakultas Sains Dan Teknologi Universitas Islam Negri (UIN) Syarif Hidayatulllah. 2011

[3] E. Ginting. Aplikasi Penjualan Berbasis Web (ECOMMERCE) Menggunakan Joomla Pada Mutiara Fashion. Bandung: Skripsi Program Studi Sistem Informasi Fakultas Teknik Universitas Widyatama. 2013.

[4] Jugianto H.M.Pengenalan Komputer. ANDI OFFSET Yogyakarta. 1989.

[5] Kendall,systems Analysis Ana Design Fifth Edition. Prentice Hall International. 2008.

[6] Kendal dan KendallAnalisis dan Perancangan Sistem. Jakarta. Indeks. 2007

[7] M. Arbani. Pengembangan Sistem Informasi Sekolah. Jakarta: Skripsi Program Studi Teknik Informatika Fakultas Dan Teknologi Universitas Islam Negeri Syarif Hidayatullah. 2011

[8] N. Adi. E-Commerce Memahami Perdagangan Modern Di Dunia Maya. Bandung: Informatika. 2006

[9] Pebriyanto.Sistem Informasi Penjualan Berbasis Web dengan Metode RAD (Studi Kasus : PT. Simtex Mechatronic Indojaya). Jakarta: Skripsi Program Studi Sistem Informasi Fakultas Sains dan Teknologi Universitas Islam Negeri Syarif Hidayatullah. 2011.

[10] Y. B. Samponu.Perancangan Sistem Informasi Bandar Udara Samratulangi Manado Berbasis Web. Manado: Skripsi Universitas Samratulangi Fakultas Teknik Jurusan Teknik Elektro Manado. 2010.

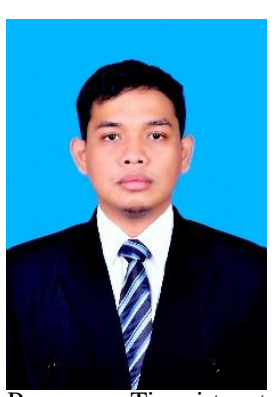

Sekilas dari penulis dengan nama lengkap Andi Wicaksono, lahir pada tanggal 27Desember 1992 di Jepara, Jawa Tengah. Anak ke-1 dari 3 bersaudara, dengan orang tua bernama Alm.Hi. Selamet Soepoyo dan ibu bernama Hj. Mastinah Marni. Dengan pendidikan pertama di Taman Kanak-Kanak Hangtua Kairagi, kemudian melanjutkan ke SDN Jondang Jepara, melanjutkan ke SMPI Darurrohman Jondang Jepara, dan pada tahun 2007 melanjutkan ke SMA Negeri 7Manado. Setelah lulus sekolah menengah atas pada tahun 2010 penulis melanjutkan ke Perguruan Tinggi tepatnya di Universitas Sam Ratulangi Manado, Fakultas Teknik, Jurusan Elektro, Program Studi Informatika. Penulis membuat skripsi untuk memenuhi syarat sarjana (S1), dengan judul Rancang Bangun Sistem Informasi Penjualan Furniture pada Galeri Ukir Mebel Berbasis Web yang di bimbing oleh dua dosen Teknik Informatika yaitu Bapak Arie S. M. Lumenta, St., MT dan Bapak Brave A. Sugiarso, ST., MT dan mengikuti sidang Skripsi pada tanggal 06 Juni 2017, sehingga pada tanggal 22 Juli 2017 penulis resmi lulus di Teknik Informatika Universitas Sam Ratulangi Manado dengan predikat sangat memuaskan. 